\title{
MENINGKATKAN KECEPATAN EFEKTIF MEMBACA (KEM) DENGAN MENGGUNAKAN METODE KLOS SISWA KELAS XI IPA 2 SMA NEGERI 6 BENGKULU SELATAN
}

\author{
Johirman \\ johirman@yahoo.co.id \\ SMA Negeri 6 Bengkulu Selatan
}

\begin{abstract}
Effective speed reading has a very important role, because with the fast reading and reading comprehension ability of qualified person could master of science and technology. Indonesian reading habits unfavorable impact negatively on the level of legibility of a person or a student. To overcome this much needed effort and creativity of teachers. Klos in the application of the method of learning to read is one way to solve the problem. The research objective of this class action is to increase the Effective Speed Reading (KEM) using klos class XI IPA 2 SMA Negeri 6 South Bengkulu This classroom action research takes place in SMA Negeri 6 South Bengkulu class XI IPA 2, the number of students 40 students. Implementation of the activities carried out through three cycles. Before the first cycle carried out the need for pre-action is the identification of methods klos and Effective Speed Reading (KEM), and then executed the first cycle as the application of methods klos, the second cycle as in implementation klos method, and the third cycle as the consolidation phase. Data were analyzed using qualitative analysis that is used to qualitative data obtained from observations of students and teachers during learning in the classroom, and the quantitative analysis is used to test Effective Speed Reading (KEM) students using klos. The results of the study in the first cycle readability level is still low, due to the effective speeds average reading rate of 87 words per minute with 18\% Independent, Instruktional rate of $38 \%$ and $44 \%$ in frustration. In the second cycle results of the study experienced a positive change that is effective speeds average reading rate of 150 words per minute with $78 \%$ Independent, Instructional rate of $18 \%$, and the frustration level of $4 \%$. The results of the study in the third cycle experienced stabilization which is the average Effective Speed Reading (KEM) 210 wpm with independent level of 100\%. The result showed that the activity of learning to read faster by using klos can improve Effective Speed Reading (KEM) students.
\end{abstract}

Keywords: Key words: Effective Speed Reading (KEM), and Closed Test

\section{PENDAHULUAN}

Berdasarkan pengalaman peneliti pembelajaran membaca baik yang dialami sendiri maupun yang diketahui selama ini, model pembelajarannya selalu mengacu pada apa yang ada pada buku paket. Teknik pengajaran membaca yang ada umumnya membaca pemahaman. Banyak teknik pengajaran yang selama ini tidak dipergunakan untuk melatih keterampilan membaca. 
Teknik-teknik itu, antara lain teknik uji rumpang. Kenyataan yang terjadi di samping kemampuan dan keterampilan yang kurang pada siswa, pengajaran membaca selalu mengacu pada teknik yang ada pada buku tersebut. Dengan demikian para siswa beranggapan pengajaran membaca tujuannya sematamata menjawab pertanyaan, mencari kata istilah yang sulit dan lain-lain. Hal ini dihadapi para siswa dengan proses yang amat lain.

Perihal lain yang selalu muncul pada pembelajaran membaca yaitu guru bahasa Indonesia pada umumnya hanya mengutamakan penyelesaian target materi dalam kurikulum yang orientasinya mengacu pada usaha meningkatkan kemampuan siswa dalam mengerjakan soal-soal, walaupun hal ini tidak selalu benar sebab soal-soal sering kurang mengacu pada keterampilan berbahasa baik keterampilan menyimak, berbicara, membaca, maupun menulis.

Faktor lain yang tidak kalah pentingnya adalah kurangnya guru bahasa Indonesia memahami dan menguasai teknik pengajaran membaca. Belum lagi memilih bahan bacaan yang seharusnya dalam pengajaran membaca guru dituntut mampu memilih bahan bacaan yang sesuai dengan tujuan dan tingkat perkembangan siswa, kompetensi siswa, minat dan tingkat kecakapan baca.

Peneliti berusaha mengungkap Kecepatan Efektif Membaca ( KEM ) siswa, karena penulis sangat prihatin dengan KEM siswa di negara kita. Kalau di negara-negara maju seperti Amerika, seorang setara SMA di negara kita (Senior High School) dalam keadaan normal sudah memiliki kecepatan membaca minimal kurang lebih 250 kata permenit, dengan pemahaman isi bacaan minimal $70 \%$. Jika dihitung kecepatan efektif membacanya $($ KEM) $=250 \mathrm{kpm} x$ $70 \%=175$ kpm. (Harjasujana, 200:88). Kalau di Amerika siswa setingkat SMA memiliki KEM terendah $\pm 175 \mathrm{kpm}$, maka di Indonesia masih tidak sedikit siswa SMA KEM tertinggi $\pm 175 \mathrm{kpm}$. Dari pengalaman peneliti membelajarkan siswa kelas XI IPA 2 SMA Negeri 6 Bengkulu Selatan, ternyata hal tersebut di atas juga terjadi. Dengan KEM \pm 175 $\mathrm{kpm}$, lalu bagaimana bisa menguasai Ilmu Pengetahuan dan Teknologi yang diharapkan melalui berbagai media cetak dalam waktu yang relatif singkat.

Berdasarkan uraian singkat di atas, peneliti mengambil tindakan, yaitu "Meningkatkan Kecepatan Efektif Membaca Dengan Menggunakan Metode Klos Siswa Kelas XI IPA 2 SMA Negeri 6 Bengkulu Selatan".

Peneliti memilih metode klos untuk meningkatkan Kecepatan Efektif Membaca (KEM) karena metode klos dapat dipakai untuk mengukur tingkat keterbacaan sebuah wacana dan untuk melatih keterampilan dan kemampuan membaca

Rumusan masalah penelitian ini adalah bagaimana penggunaan metode Klos bisa meningkatkan Kecepatan Efektif Membaca (KEM) siswa kelas XI IPA 2 SMAN 6 Bengkulu Selatan

Tujuan penelitan tindakan kelas ini adalah meningkatkan Kecepatan Efektif Membaca (KEM) siswa kelas XI IPA 2 SMAN 6 Bengkulu Selatan dengan menggunakan metode klos .

Penelitian ini diharapkan dapat bermanfaat:

a. Bagi siswa: Hasil penelitian ini diharapkan dapat meningkatkan keterampilan berbahasa dan 
terjadi kemajuan belajar pada mata pelajaran lain

b. Bagi peneliti (guru): Dapat meningkatkan profesionalisme dan bisa digunakan untuk pengembangan profesi dalam perolehan angka kredit untuk naik ke golongan IV $b$.

c. Bagi guru lain: Memberikan motivasi dan referensi modelmodel pembelajaran yang inovatif.

d. Bagi sekolah: Adanya guru-guru (para peneliti) melakukan penelitian tindakan kelas berarti proses pembelajaran di kelas sangat berkualitas sehingga terjadi perubahan positif mengarah pada sekolah unggul.

\section{METODE PENELITIAN}

Data yang dikumpulkan dalam penelitian ini berupa, silabus pembelajaran, rencana pelaksanaan pembelajaran (RPP), hasil Kecepatan Efektif Membaca (KEM) siswa, dan hasil observasi terhadap kegiatan pembelajaran.

Sumber data dalam penelitian ini adalah Interaksi siswa dan Guru di kelas XI SMA Negeri 6 Bengkulu Selatan Tahun Pelajaran 2015/2016, ketika pelaksanaan pembelajaran.

Dalam penelitian tindakan kelas ini menggunakan dua teknik analisis data, yaitu analisis kualitatif dan analisis kuantitatif. Analisis kualitatif diperoleh dari hasil pengamatan siswa dan guru selama berlangsungnya tindakan di kelas. Sedangkan, analisis kuantitatif digunakan terhadap hasil tes Kecepatan
Efektif Membaca (KEM) siswa dengan menggunakan Metode Klos.

Rumus yang dipakai untuk mengetahui Kecepatan Efektif Membaca adalah sebagai berikut :

$$
\begin{aligned}
& \frac{K}{W m} \frac{K}{W m} \times \frac{B}{S I}=\mathrm{Kpm} \\
& \frac{K}{W d: 60} \times \frac{B}{S I}=\mathrm{Kpm} \\
& \frac{K}{W m}(60) \times \frac{B}{S I}=\mathrm{Kpm}
\end{aligned}
$$

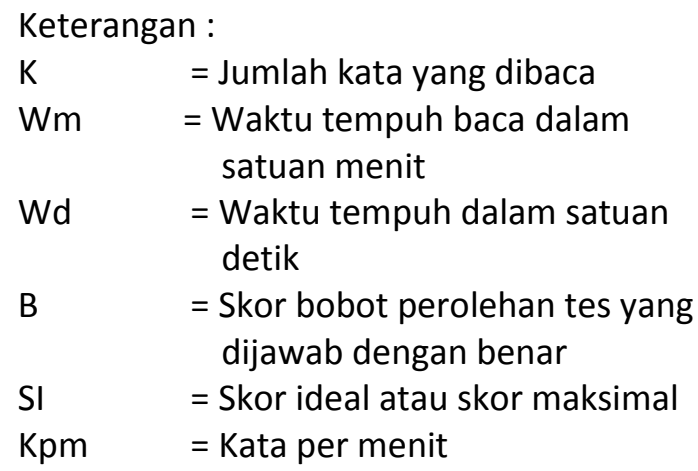

Siswa dikatakan berhasil membaca (dalam katagori utama) kalau kecepatan membaca minimal $250 \mathrm{kpm}$ dan kemampuan memahami bacaan minimal $70 \%$, itu berarti siswa dikatakan berhasil membaca (tuntas) atau sesuai dengan KKM (Kriteria Ketuntasan Minimal) yaitu jika Kecepatan Efektif Membaca (KEM) minimal 175 kpm.

Hal itu didasarkan pada pendapat Harjasujana yang mangatakan bahwa, KEM minimal untuk klasifikasi pembaca adalah : SD (140 kpm), SLTP (140-175 kpm), SLTA (175-245 kpm), dan Perguruan Tinggi (245-280 kpm). (Harjasujana, 2000:110) 


\section{HASIL DAN PEMBAHASAN}

\section{A. Hasil Penelitian}

Ketika peneliti membelajarkan siswa tentang membaca cepat, ternyata kemampuan Kecepatan Efektif Membaca (KEM) siswa masih rendah. Peneliti berusaha mengungkap Kecepatan Efektif Membaca (KEM) siswa, karena penulis sangat prihatin dengan KEM siswa di negara kita. Kalau di negara-negara maju seperti Amerika, seorang setara SMA di negara kita (Senior High School) dalam keadaan normal sudah memiliki kecepatan membaca minimal kurang lebih 250 kata permenit, dengan pemahaman isi bacaan minimal $70 \%$. Jika dihitung kecepatan efektif membacanya $($ KEM) $=250 \mathrm{kpm} \times 70 \%=$ 175 kpm. (Harjasujana, 200:88). Kalau di Amerika siswa setingkat SMA memiliki KEM terendah $\pm 175 \mathrm{kpm}$, maka di Indonesia masih tidak sedikit siswa SMA KEM tertinggi $\pm 175 \mathrm{kpm}$. Dari pengalaman peneliti membelajarkan siswa kelas XI IPA 2 SMA Negeri 6 Bengkulu Selatan, ternyata hal tersebut di atas juga terjadi. Dengan KEM \pm 175 $\mathrm{kpm}$, lalu bagaiman bisa menguasai Ilmu Pengetahuan dan Teknologi yang diharapkan melalui berbagai media cetak dalam waktu yang relatif singkat. Pelaksanaan penelitian Tindakan ini dilaksanakan 3 siklus. Setiap siklus terdiri dari dua pertemuan. Setiap pertemuan memerlukan waktu 2 × 45 menit. Masing-masing siklus meliputi (a) persiapan tindakan, (b) pelaksanaan tindakan, (c) observasi dan evaluasi, dan (d) analisis dan refleksi. Secara rinci pelaksanaan tindakan sebagai berikut :

\section{Pra Tindakan}

Siswa mendengarkan penjelasan tentang metode klos dan Kecepatan Efektif Membaca (KEM), kemudian siswa berdiskusi tentang penggunaan metode klos untuk meningkatkan Kecepatan Efektif Membaca (KEM), bahkan hal ini dikondisikan menjadi diskusi kelas. Ternyata siswa sangat tertarik dengan metode klos. Hal ini terlihat banyaknya siswa yang bertanya dan juga memberikan tanggapan. Pertanyaan maupun tanggapan berkisar tentang metode klos dan KEM. Dengan temuantemuan seperti itu merupakan jalan yang sangat baik untuk membelajarkan siswa dalam rangka meningkatkan kecepatan membaca dan kemampuan memahami bacaan yang dilaksanakan pada siklussiklus yang direncanakan.

\section{Siklus I}

\section{Persiapan Tindakan}

Untuk melaksanakan tindakan sebelumnya memerlukan persiapanpersiapan yaitu : menyusun rencana pelaksanaan pembelajaran yang mengacu pada silabus yang telah dibuat guru. Agar proses pembelajaran lancar perlu bahan ajar tentang metode klos dan Kecepatan Efektif Membaca (KEM) serta menyiapkan bacaan yang sesuai dengan kriteria klos. Perolehan hasil penelitian dipersiapkan alat observasi baik untuk siswa maupun guru. Alat observasi berupa instrumen metode klos, instrumen alat penilaian individu KEM siswa, instrumen observasi KEM, instrumen observasi aktivitas guru, dan angket siswa. Peneliti dibantu observer dari guru dan juga pengamat dari siswa. 
2. Pelaksanaan Tindakan

Pelaksanaan tindakan pada siklus I langkah-langkah pembelajaran sebagai berikut :

a) Kegiatan awal siswa membentuk kelompok. Dari 40 siswa setiap nomor absen ganjil sebagai kelompok responden (atau kelompok yang diteliti), dan nomor absen genap sebagai kelompok pengamat atau pencatat waktu dan menghitung Kecepatan Efektif Membaca (KEM) responden. Dengan demikian, setiap nomor absen ganjil berpasangan dengan nomor absen genap.

b) Siswa mencatat tujuan pembelajaran yang akan dicapai.

c) Guru membagi siswa menjadi kelompok ganjil dan genap

d) Siswa kelompok A yaitu kelompok nomor absen ganjil membaca wacana yang sudah disediakan dan siswa kelompok B yaitu kelompok nomor absen genap mencatat dan menghitung responden.

e) Siswa kelompok B (sebagai pengamat) secara individu mengukur tingkat keterbacaan responden (pasangannya)

f) Tahap berikutnya kelompok yang semula sebagai responden berganti sebagai kelompok pengamat yang tugasnya mencatat waktu dan menghitung KEM responden, begitu juga kelompok yang semula sebagai pengamat berganti menjadi kelompok responden

g) Kegiatan akhir siswa berdiskusi tentang kendala-kendala meningkatkan KEM dengan menggunakan Metode Klos sebagai acuan refleksi.

\section{Observasi dan Evaluasi}

Pembelajaran membaca cepat dengan menggunakan metode klos ini, siswa sangat antusias. Pada awal siswa dengan senang membentuk kelompok dengan setting yang sederhana tetapi menarik yaitu setiap siswa berpasangan yang saling berhadapan yaitu antara siswa nomor absen ganjil dengan siswa nomor absen genap.

Sejumlah 40 siswa dari data aktivitas siswa dalam pembelajaran membaca dan sekaligus sebagai penerapan pengelolaan pembelajaran secara kelompok maupun individu dapat diperoleh rincian tingkat keterbacaan siswa dalam membaca cepat dengan menggunakan metode klos sebagai berikut : jumlah kata dalam wacana \pm 630 kata. Sebagai alat ukur permenit standarnya 250-350 kata. Setelah ditetapkan 2 menit. waktu baca, kenyataan di kelas belum mau berhenti, sehingga terjadi penambahan waktu menjadi 3 menit. Dengan demikian, fungsi alat ukur berubah menjadi alat ajar yaitu per menit antara 150 sampai 200 kata.

Berdasarkan laporan pengamat ketika mengobservasi aktivitas guru/peneliti pada saat berlangsungnya pembelajaran, pada bagian awal terlihat bahwa guru/peneliti sudah menjelaskan tujuan pembelajaran, dan juga telah memotivasi siswa agar bisa meningkatkan KEM siswa. Ketika siswa membentuk kelompok baik kelompok responden maupun kelompok pengamat, guru juga membantu. Pemodelan metode klos untuk meningkatkan KEM. Penilaian yang dilakukan selalu dikondisikan mengacu pada kriteria klos maupun KEM. Diskusi untuk mengetahui kendala-kendala KEM dilaksanakan 
sebagai acuan refleksi pada siklus berikutnya

$$
\text { Dapat dijabarkan hasil uji }
$$
kemampuan isian rumpang yaitu: (1) Tingkat Independen 7 siswa $=17,5 \%$, (2) Tingkat Instruksional 15 siswa $=37,5 \%$, (3) Tingkat Frustasi 18 siswa $=45 \%$. Kecepatan Efektif Membaca (KEM) siswa yang tuntas atau sesuai dengan Kriteria Ketuntasan Minimal yaitu 175 kata per menit ke atas adalah 0 siswa Siswa yang tidak tuntas atau kurang dari 175 kata permenit ke atas adalah 40 siswa Siswa yang KEMnya tertinggi $170 \mathrm{kpm}$, KEM terendah $=30 \mathrm{kpm}$, dan KEM rata-rata 87 kpm (terdapat dalam lampiran 1)

Pada diskusi kelompok telah terekam masalah yang dihadapi siswa pada saat membaca cepat, yaitu masalah tingkat pengetahuan bahasa $80 \%$ atau 32 siswa, masalah kemampuan kognitif $80 \%$ atau 32 siswa, dan masalah pengalaman membaca $90 \%$ atau 36 siswa. (terdapat dalam lampiran 2)

\section{Refleksi}

Refleksi diperoleh dari pengamatan dan hasil diskusi dengan kolaboratif, diperoleh berdasarkan selama tindakan berlangsung. Hasil pengamatan diskusi kaloboratif materi setelah selesai penelitian tindakan.

Dari masalah yang dihadapi siswa selama membaca dengan menggunakan metode klos, maka dapat direfleksikan sebagai berikut :

Siswa perlu meningkatkan pengetahuan bahasa Indonesia dengan jalan sering membaca Kamus Bahasa Indonesia, dan tentang teori kebahasaan.

Siswa perlu meningkatkan kemapuan kognitif dengan jalan meningkatkan daya nalar dan kepekaaan untuk mengerti dan memahami isi/pesan yang terkandung dalam suatu bacaan yang seefisien mungkin

Siswa harus sering membaca untuk meningkatkan pengalaman membaca. Orang yang sering membaca jauh berbeda KEMnya dengan orang yang jarang membaca.

Guru/peneliti perlu memproduksi wacana yang dominan dan menghindari wacana yang terpinggirkan yaitu : wacana yang berfungsi membentuk dan mengkondisikan wacana aktual. Wacana dominan memberikan arahan bagaimana suatu objek harus dibaca dan dipahami. Wacana yang dominan memberikan daya tarik tersendiri bagi pembaca, sehingga siswa sangat senang ketika membaca karena sesuatu yang baru. Berdasarkan temuan hasil refleksi di atas dilakukan perbaikan untuk perencanaan siklus berikutnya.

\section{Siklus II}

\section{Persiapan Tindakan}

Pada persiapan tindakan kelas di siklus II ini seperti juga pada persiapan tindakan kelas di siklus I, namun di siklus ini persiapannya sebagai tindak lanjut. Rencana pelaksanaan pembelajaran (RPP) dibuat oleh peneliti/guru dibantu oleh dua orang pengamat dari guru mata pelajaran sejenis. Bacaan dipersiapkan sebagai wacana yang aktual (dominan) berjudul: "Tembak di Tempat Perusuh, Pejarah dan Koruptor Bahasa Indonesia". Untuk kelancaran proses pembelajran maka pembelajaran dilengkapi bahan ajar. Pada tahap observasi peneliti dibantu dua orang pengamat dari guru mata pelajaran sejenis dan pengamat dari siswa, terutama pada penghitungan KEM. 
2. Pelaksanaan Tindakan

Pelaksanaan tindakan pada siklus

II ini guru/peneliti menerapkan pembelajaran dengan kegiatan awal siswa membentuk kelompok seperti pada siklus I dan siswa mencatat tujuan pembelajaran. Siswa nomor absen ganjil membaca teks non sastra berjudul "Tembak di Tempat Perusuh, Pejarah dan Koruptor Bahasa Indonesia" yang panjang wacana kurang lebih 400 kata dan waktu membaca yang disediakan 2 menit. Setelah 2 menit bacaan diambil oleh guru, kemudian siswa tersebut diberi teks lagi dengan teks yang sama tetapi dirumpangi sebanyak 15 rumpangan, dan siswa diberi kesempatan mengerjakan selama 10 menit. Siswa yang nomor absen genap sebagai pengamat yang bertugas mengukur tingkat keterbacaan responden (pasangannya) Tahap berikutnya kelompok yang semula sebagai responden berganti sebagai kelompok pengamat yang tugasnya mencatat waktu dan menghitung KEM responden, begitu juga kelompok yang semula sebagai pengamat berganti menjadi kelompok responden

\section{Observasi dan Evaluasi}

Pada observasi dan evaluasi di siklus II ini kegiatan pembelajaran sangat kondusif. Guru menerapkan pembelajaran berpusat pada siswa, sehingga kondisi kelas sangat bermakna dan menyenangkan. Sejalan dengan itu penilaian yang diterapkan adalah penilaian proses yaitu ketika siswa menerapkan metode klos untuk meningkatkan KEM.

Hasil uji kemampuan isian rumpang pada tingkat indipenden sebanyak 31 orang atau 77, $5 \%$, pada tingkat instrusional sebanyak 7 orang atau 17, $5 \%$ dan pada tingkat frustasi/gagal sebanyak 2 orang atau 5 $\%$ Hal ini banyak mengalami peningkatan apabila dibandingkan dengan siklus I. Kecepatan Efektif Membaca (KEM) siswa pada penelitian ini terekam sebagai berikut : (1) KEM siswa yang tuntas sesuai dengan kriteria ketuntasan minimal (KEM=175 kpm ke atas) adalah 18 siswa atau 45\%, yang tidak tuntas 22 siswa atau 55\%. Hal ini pun mengalami kenaikan apabila dibandingkan dengan siklus I. Pada siklus II ini KEM tertinggi 217 kpm, terendah 70 $\mathrm{kpm}$, dan rata-rata $150 \mathrm{kpm}$. (terdapat dalam lampiran 1)

Pada diskusi kelompok terekam permasalahan mulai terpecahkan. Permasalahan yang dikelompokkan menjadi 3 klasifikasi yaitu tingkat pengetahuan bahasa, tingkat kemampuan kognitif, dan klasifikasi pengalaman membaca mulai menurun dengan jalan keluar yang sudah diterapkan. Pada tingkat pengetahuan bahasa siswa yang mengalami kendala di bidang itu hanya 12 siswa atau 30\%, dan di bidang kemampuan kognitif 16 siswa atau 40\%, dan pada pengalaman membaca 19 orang atau 47, 5\%. (terdapat dalam lampiran 2).

\section{Refleksi}

Permasalahan siswa yang sudah ada jalan keluarnya sebagai pelaksanaan refleksi perlu diteruskan, mengingat hasilnya sangat membanggakan terutama siswa diharapkan terus mengembangkan pengalaman membaca dengan cara sering membaca untuk melatih Kecepatan Efektif Membaca (KEM) 
Siklus III

\section{Persiapan tindakan}

Berdasarkan hasil pengamatan siklus 2 saja dan hasil diskusi dengan kaloboratif pada siklus II, siklus ke III ini merupakan bagian pemantapan pelaksanaan penelitian tindakan kelas ini. Pada persiapan tindakan, guru/peneliti mempersiapkan rencana pelaksanaan pembelajaran (RPP), dan bahan ajar peneliti langsung menggunakan bacaan 250 kata dengan waktu membaca direncanakan hanya 1 menit. Lembar observasi untuk mengetahui KEM maupun angket untuk siswa juga dipersiapkan agar penelitian tindakan kelas ini bisa maksimal.

\section{Pelaksanaan Tindakan}

Pelaksanaan tindakan pada siklus III ini merupakan siklus akhir. Guru/ peneliti menerapkan kegiatan awal siswa membentuk kelompok seperti pada siklus sebelumnya. Siswa juga mencatat tujuan pembelajaran yang akan dicapai Siswa yang nomor absen ganjil membaca teks non sastra berjudul "Tertib Lalu Lintas", yang panjang wacana kurang lebih 250 kata dan waktu bacaan yang disediakan hanya 1 menit. Setelah 1 menit bacaan diambil oleh guru, kemudian siswa tersebut diberi teks lagi dengan teks yang sama tetapi ada rumpangan sebanyak 15 rumpangan Siswa mengerjakan dengan waktu yang disediakan 10 menit. Siswa yang nomor absen genap sebagai pengamat yang bertugas mengukur tingkat keterbacaan responden. Selanjutnya kelompok yang semula sebagai responden berganti sebagai kelompok pengamat dan kelompok yang semula sebagai pengamat berganti menjadi kelompok responden

\section{Observasi dan Evaluasi}

Dari hasil observasi siswa teman sebaya, maupun dari pengamat (guru mata pelajaran sejenis) bahwa hasil uji kemampuan isian rumpang yaitu : (1) tingkat independen $=40$ siswa atau 100 $\%$, (2) tingkat instruksional = 0 siswa atau $0 \%$, dan (3) tingkat frustasi/gagal $=0$ siswa atau $0 \%$. Hasil observasi juga terekam Kecepatan Efektif Membaca (KEM) siswa yang tuntas atau $175 \mathrm{kpm}$ ke atas sebanyak 40 orang atau $100 \%$, KEM tertinggi $250 \mathrm{kpm}$, KEM terendah $156 \mathrm{kpm}$, dan rata-rata $210 \mathrm{kpm}$. (terdapat dalam lampiran 1)

\section{Refleksi}

Di akhir siklus ini guru/peneliti memberikan angket kepada siswa tentang pelaksanaan pembelajaran, ternyata siswa menyambut positif pelaksanaan pembelajaran tersebut. Pada proses pembelajaran $100 \%$ siswa menjawab ya pada point mudah diterima ketika menjelaskan metode klos untuk meningkatkan KEM, 100\% menjawab ya pada point memberi kesempatan anda untuk bertanya tentang metode klos dan KEM, 50\% menjawab ya pada pernyataan membantu anda ketika membentuk kelompok responden dan kelompok pengamat, sebaliknya kelompok pengamat menjadi kelompok responden, $100 \%$ siswa menjawab ya pada pernyataan mengkondisikan anda untuk melaksanakan pemodelan metode klos untuk meningkatkan KEM, $100 \%$ siswa menjawab ya pada pernyataan anda diajak berdiskusi tentang kendalakendala KEM, dan $100 \%$ siswa menjawab 
ya pada pernyataan anda diajak berdiskusi tentang kelebihan dan kelemahan metode klos. Pada penilaian $100 \%$ siswa menjawab ya pada pernyataan anda diberi kesempatan sebagai pengamat untuk menilai teman sendiri, dan $100 \%$ menjawab ya pada pernyataan bahwa penilaian didasarkan pada kriteria klos dan kriteria KEM. Hasil pembelajaran $90 \%$ siswa menjawab ya pada pernyataan anda sangat senang dengan model pembelajaran metode klos untuk meningkatkan KEM, dan 100\% siswa menjawab ya pada pernyataan dan KEM bertambah ketika menggunakan metode klos(terdapat pada lampiran 3)

Dengan demikian pelaksanaan pembelajaran sampai dengan siklus III mengalami keberhasilan.

\section{B. Pembahasan}

Pada pelaksanaan tindakan pembelajaran bahasa Indonesia harus bisa menerapkan keterampilan berbahasa. Ada 4 keterampilan berbahasa yaitu menyimak, berbicara, dan menulis baik itu tentang kebahasaan maupun kesastraan.

Membaca merupakan bagian penting dari 4 keterampilan berbahasa. Membaca banyak ragamnya termasuk membaca cepat. Tidak sedikit siswa Kecepatan Efektif Membaca (KEM)nya di bawah $175 \mathrm{kpm}$, namun dengan menggunakan metode klos untuk meningkatkan KEM siswa. Pada Penelitian Tindakan Kelas (PTK) ini pada siklus ke III ternyata semua siswa KEMnya $175 \mathrm{kpm}$ ke atas. Menurut Kamidjan (1996:68) metode klos dapat dipakai untuk mengukur tingkat keterbacaan sebuah wacana yaitu (a) Dapat dipakai untuk menguji tingkat kesukaran dan tingkat kemudahan suatu wacana, (b) Dapat mengklasifikasikan pembaca menjadi 3 kelompok, yaitu : independen (tingkat bebas), instruksional (tingkat pengajaran), dan frustasi (gagal), (c) Serta untuk mengetahui kelayakan wacana sesuai dengan kemampuan siswa (Kamidjan, 1996:68).

Sejalan dengan itu beliau juga mengatakan teknik klos juga dapat dipakai untuk melatih keterampilan dan kemampuan membaca. Yang diperhatikan dalam melatih keterampilan dan kemampuan baca ialah: (a) dalam menggunakan isyarat sintaksis, (b) dalam menggunakan isyarat semantik, (c) dalam menggunakan isyarat skematis, (d) dalam menggunakan jumlah kosakata, (e) dalam melatih daya nalar pembaca, serta (f) dalam melatih pemahaman bacaan (Kamidjan, 1996:69).

Kegiatan awal pembelajaran pada pra tindakan terlihat semua siswa tertarik penjelasan guru tentang model/teknik klos dan penjelasan KEM (Kecepatan Efektif Membaca) seseorang, bahkan pada saat berdiskusi tentang metode tersebut siswa sangat antusias bertanya dan memberikan komentar maupun pendapat. Hal ini sangat relevan apabila metode klos digunakan untuk meningkatkan KEM, karena siswa ada kepedulian, itu berarti pembelajaran yang bermakna dan menyenangkan telah terbentuk, dan sangat baik untuk memulai tindakan baik siklus I maupun siklus-siklus berikutnya.

Pelaksanaan refleksi dengan jalan diksusi kelompok maupun diskusi kelas telah teruji bahwa kendala-kendala KEM harus segera diatasi agar KEM siswa meningkat. Menurut Harjasujana (2000:90) Kendala-kendala KEM 
meliputi: lemahnya pengetahuan bahasa, kurangnya kemampuan kognitif, dan pengalaman membaca yang memprihatinkan. Masalah pengetahuan bahasa jalan keluarnya siswa diharapkan sering membaca kamus bahasa Indonesia, dan untuk kemampuan kognitif, siswa diharapkan meningkatkan daya nalar dan kepekaan untuk mempermudah memahami isi/pesan yang terkandung dan yang terakhir yaitu pada kendala pengalaman membaca diharapkan siswa sering membaca karena seseorang yang sering membaca KEMnya jauh berbeda dengan orang yang jarang membaca itu berarti bahwa untuk mencapai tujuan perlu melihat sebab, kalau sudah tahu sebab, baru melangkah mencari jalan keluar.

\section{SIMPULAN}

Berdasarkan hasil penelitian tindakan kelas ini dapat disimpulkan sebagai berikut:

a. Kemampuan kecepatan membaca siswa rendah karena teknik pembelajaran membaca yang selama ini tidak diarahkan untuk melatih keterampilan membaca, dan model pembelajarannya selalu mengacu pada buku yang ada, sehingga para siswa beranggapan pengajaran membaca tujuannya semata-mata menjawab pertanyaan, mencari kata/istilah yang sulit dan lain-lain. Hal ini dihadapi siswa dengan proses yang amat lamban.

b. Metode klos dapat dipakai untuk mengukur tingkat keterbacaan sebuah wacana yaitu dapat dipakai untuk menguji tingkat kesukaran dan tingkat kemudahan suatu wacana, serta dapat mengklasifikasi pembaca menjadi 3 kelompok yaitu : independen (tingkat bebas), instruksional (tingkat pengajaran), dan frustasi (gagal). Di samping itu metode klos juga bisa digunakan untuk mengetahui kelayakan wacana sesuai dengan kemampuan siswa, dan dapat pula dipakai untuk melatih keterampilan dan kemampuan baca.

c. Hasil analisis data menunjukkan bahwa aktivitas pembelajaran membaca cepat dengan menggunakan metode klos dapat meningkatkan Kecepatan Efektif Membaca (KEM) siswa.

d. Kecepatan Efektif Membaca (KEM) merupakan perpaduan antara kecepatan membaca dengan kemampuan memahami bacaan.

e. Kecepatan Efektif Membaca (KEM) dipengaruhi oleh faktor tingkat pengetahuan bahasa, pengetahuan kognitif, dan pengalaman membaca siswa. Kendala pada tingkat pengetahuan bahasa pemecahannya dengan jalan sering membaca kamus bahasa Indonesia dan teori kebahasaan sedangkan kendala pada pengetahuan kognitif pemecahannya dengan jalan meningkatkan daya nalar dan kepekaan untuk mengerti dan memahami isi/pesan yang terkandung dalam suatu bacaan yang seefisien mungkin. Pada kendala pengalaman membaca pemecahannya siswa harus sering membaca karena orang yang sering membaca KEMnya jauh berbeda dengan orang yang jarang membaca. 


\section{DAFTAR PUSTAKA}

Depdikbud, 1999. Penelitian Tindakan. Jakarta: Direktorat Jendral Pendidikan Dasar dan Menengah, Direktorat Menengah Umum.

Eriyanto. 2003. Analisis Wacana. Yogyakarta: LKIS.

Harjasujana, Akhmad Slamet, 1996. Membaca 2. Jakarta: Depdikbud Direktorat Jendral Pendidikan Dasar dan Menengah, Direktorat Menengah Umum. Bagian Proyek Penataran Baru SLTP Setara D. III.

Kasmidjan, Drs. 1996. Teori Membaca. Surabaya: Jurusan Pendidikan Bahasa dan Sastra Indonesia Fakultas Pendidikan Bahasa dan Seni.

Poerwodarminto, WJS. , 1994, Bahasa Indonesia untuk Karang Mengarang. Yogya: UP. Indonesia.
Soedarso, 2000, Speed Reading Sistem Membaca Cepat dan Efektif. Jakarta: PT Gramedia Pustaka Utama.

Subyakto, Sri Utari, Dr. 1988, Metodologi Pengajaran Bahasa. Jakarta: Depdikbud Direktorat Jenderal Pendidikan Tinggi, Proyek Pengembangan Lembaga Pendidikan Tenaga Kependidikan.

Suranto, Basowi, Sukidin. 2002. Manajemen Penelitian Tindakan Kelas. Insan Cendekia

Tim Pelatih Proyek PGSM, 1999. Penelitian Tindakan Kelas (PTK), Jakarta: Depdikbud Direktorat Pendidikan Tinggi, Pengembangan Guru Sekolah Menengah. 